\title{
International non-governmental organisations: a conceptual discussion
}

Organizações internacionais não-governamentais: uma discussão conceitual

João Victor Guedes Neto ${ }^{1}$

\begin{abstract}
This paper aims at evidencing how international non-governmental organisations (INGOs) are managing to be heard, recognized and trusted in order to insert the civil society into international fora of decision-making. As both the literature and the topic are vast, this paper focuses on contributing to the current state-of-the-art of international relations by introducing a conceptual discussion on the key elements present in INGOs which have authoritative legitimacy to influence global governance.
\end{abstract}

Keywords: Global Governance; International non-governmental organisations; civil society.

\section{RESUMO}

o objetivo deste artigo é evidenciar como organizações não-governamentais internacionais (INGOS) estão agindo para ser ouvidas, reconhecidas e confiadas a fim de inserir a sociedade civil em fóruns internacionais de tomada de decisões. Como a literatura e o tópico são vastos, este artigo foca em contribuir para o atual estado da arte das relações internacionais introduzindo uma discussão conceitual sobre os elementos chave presentes em INGOs que possuem legitimidade de autoridade para influenciar a governança global.

Palavras-chave: Governança global; Organizações não-governamentais internacionais; sociedade civil.

1 Mestrando em Economia Pública, Direito e Política na Leuphana Universität Lüneburg; Lüneburg, Alemanha. 


\section{Introduction}

The history of humanity has always been built through globalisation patterns, where, even in the lack of advanced technologies and peace-oriented methods, nations developed themselves by their international relations which guided the world to either voluntary or involuntary global standards that, in many cases, were stronger than cultural and political divergences. After the end of the II World War and the recent fall of the Berlin's Wall, the world started looking for a consensual scenario that would be able to facilitate its transnational dialogue, reduce its concerns over power and political conflicts, and to promote values that could boost life quality standards.

Global politics, in this case, regarded not only States but also individual citizens that were able to mobilize themselves through international nongovernmental organisations (INGOs) managing to reach an international regime that defers voice and authority to non-State actors which interact in the draft of the above-mentioned consensual scenario. As it will be described in this paper, this consensual scenario is the global governance.

The main goal of this study is to contribute to the current state-of-the-art of international relations by introducing a conceptual discussion on the key elements present in international non-governmental organizations which have authoritative legitimacy to influence global governance. In the first section, I make use of the relevant literature to demonstrate the importance of core elements as independence, nonprofitable ends, desirable non-violent goals and bureaucracy. I follow discussing the influence of international regimes on the work of civil society actors and their expected impact in global governance.

\section{Non-Governmental Organisations in an International Scenario}

As the aim of this study is to move towards an efficient model of nongovernmental action, this chapter will be directed to point out concepts and parameters to delimit the management of INGOs and the development of their influence over world politics. Understanding efficiency as the ability to promote change in specific issues of global governance, this approach will admit that efficiency can be explained by the 
ability to become a recognized authority over a specific theme, what shall be enough not only to be heard in transnational fora but also to provoke political changes and to promote specific public policies that matches the referred INGOs' interest areas. It will be given a focus to (a) the boundaries of the studied organizations; (b) the international regime required for its maximum efficiency; and (c) global governance as the main target of the civil activism described on this paper.

\subsection{International Non-Governmental Organisations}

Several authors presented concepts to define which organisations should be included - or not - in the frame of an INGO. To delimit the existing broad range of concepts, I will follow the ones elaborated by Willetts (2002) on Non-Governmental Organisations (NGOs) and Barnett and Finnemore (2005) on International Organisations (IOs).

Among the several guidelines designed by Willetts (2002), I am going to focus on the need of NGOs to be (1) "independent from the direct control of any government" and not "constituted as a political party"; (2) "non-profit making"; and (3) non-criminal nor violent. Based on these parameters, Willets (2002) states that "an NGO is defined as an independent voluntary association of people acting together on a continuous basis, for some common purpose, other than achieving government office, making money or illegal activities“.

To define a general concept of INGOs, we will add to that what Barnett and Finnemore (2005) stated about IOs affirming that they "construct the social world in which cooperation and choice take place" helping to define "interests that states and other actors come to hold". To that, they must (4) be organized as a bureaucracy; and to pursue "liberal social goals that are widely viewed and desirable and legitimate", what can be summed to the third concept of nonviolence (BARNETT and FINNEMORE, 2005).

\subsubsection{Independence}

One of the most common problems when dealing with the management of INGOs are the continuous attempts of individual governments or transnational organisations to influence "the [I]NGO community in a particular field, by establishing 
[I]NGOs that promote their policies" and by supporting "field costs for projects" related to its interests (Willetts, 2002). It happens because INGOs are able to "provide essential functions" as "public goods", to "collect information, establish credible commitments, monitor agreements, and generally helps states overcome problems associated with collective action and enhance individual and collective welfare" (Barnett and Finnemore, 2005).

A practical example is the European Youth Foundation that is operated as a "fund established in 1972 by the Council of Europe to provide financial support for European youth activities" (EYF, 2010). As its website shows, this fund that is sustained by 47 countries approved a total amount of $€ 678,000$ that was directed to 51 different events hosted by European youth NGOs.

In this scenario, the main concern regarding these governmental funds is that "[I]NGOs need substantial resources to run their operational programs" and even if "nominally [I]NGOs may appear to be independent when they design their own programs", they may suffer indirect governmental influence if its programmes are "designed to make it more likely that government grants or contracts will be forthcoming" (Willetts, 2002).

Following the restriction of being "independent from the direct control of any government" and not "constituted as a political party", INGOs are able to avoid the controversial labels of Governmental-Oriented Non-Governmental Organisation (GONGO) and Quasi Non-Governmental Organisation (QUANGO) that may "damage an [I]NGO for such a perception to arise" (Willetts, 2002).

\subsubsection{Non-Profitable}

If considering its literal sense as Uphoff (2002) did when introducing this theme, it is possible to affirm that "any institutions not in the public sector can be called 'non-governmental organisations'”. On the other hand, "it is true that business enterprises, for example, differ from typical [I]NGOs in that the former operate 'for profit' while the latter do not". 
Cornforth (2003) goes ahead determining that non-profitable INGOs' "trustees themselves should not benefit financially from the trust", distinguishing them from business companies' board members even if in both cases employees may be paid. Still according to Cornforth (2003), "the board represents or reflects those who act as 'guardians' of the charity's mission", what means that, as it will be better explained ahead, the main role of an INGO board is not to guide the institution taking into account their personal beliefs - as it may happen in business companies - but, on the contrary, "to serve the charity's intended beneficiaries as set out in the trust deed".

That "charity's mission" or "trust deed" shall remain unchanged as a way to meet the beneficiaries' needs, as Uphoff (2002) endorses. He also suggests that, even differing in the profit theme, charity organisations should deal with its stakeholders (including clients, members and beneficiaries) in a "take it or leave it" way as a form to preserve its original values.

\subsubsection{Desirable Non-Violent Goals}

As Barnett and Finnemore (2005) states, "I[NG]Os now manage conflicts, both international and civil (...), promote economic growth and free trade" and are "actively involved in protecting human rights around the globe". Doh and Teegen (2003) details it saying that these organisations "are increasingly influencing both government and corporate policy directly by undertaking research, organizing boycotts, and often highlighting the shortcomings of both business and governmental actions in terms of social, ethical and environmental responsibility". They mention that INGOs are also working "cooperatively with companies and governments to positively influence government policy approaches and corporate social policies" showing that it is not about popular pressure and civil society mobilization. Nevertheless, it is only possible because these INGOs' "goals (...) are widely viewed as desirable and legitimate" providing legitimacy and authority to represent civil society' wishes when convincing government to follow their beliefs (BARNETT and FINNEMORE, 2005).

Through a quick search among some of the most important INGOs of the planet, it is possible to see that, for example, the Amnesty International "campaigns to end grave abuses of human rights" and that their "vision is for every person to enjoy all the rights 
enshrined in the Universal Declaration of Human Rights and other human rights standards" (Amnesty International, 2010); Cato Institute is a "public policy research organisation (...) dedicated to the principles of individual liberty, limited government, free markets and peace" (Cato Institute, 2010); Chatham House's mission is "to be a world-leading source of independent analysis, informed debate and influential ideas on how to build a prosperous and secure world for all (Chatham House, 2010); and the Wikileaks declares its goal as "to bring important news and information to the public" providing "an innovative, secure and anonymous way for sources to leak information to our journalists" (Wikileaks, 2010). Thus, human rights, economic freedoms, international dialogue and free speech, among others, may be clearly perceived either by civil society and government leaders as desirable and legitimate values to be supported by successful INGOs.

\subsubsection{Bureaucratic}

As Barnett and Finnemore (2005) wrote, "[Max] Weber recognized that bureaucracy is a uniquely authoritative (and powerful) social form in modern societies because of its rational-legal (i.e., impersonal, technocratic) character". Furthermore, the use of bureaucratic managerial models allows INGOs to adopt procedures that "legitimate and justify" its trustees "with reference to the rules and regulations of the bureaucracy". In a more detailed approach, it is possible to say that successful INGOs' must have its bureaucracy constituted by four central features (Barnett and Finnemore, 2005):

1. Hierarchy, "for each official has a clearly defined sphere of competence within a division of labor and is answerable to superiors"; 2. Continuity, "where the office constitutes a full-time salary structure that offers the prospect of regular advancement"; 3. Impersonality, "where the work is conducted according to prescribed rules and operating procedures that eliminate arbitrary and politicized influences"; and 4. Expertise, "where officials are access selected according to merit, are trained for their function, and control access to knowledge stored in files" (Barnett and Finnemore, 2005).

In other words, bureaucratic models give long life to INGOs showing that even if their boards and trustees are changed, they will remain being organised and managed in 
the same way. In the end, it promotes a greater level of trust from governments and civil society as every interested citizen will have a clear overview on (1) who are the headers; (2) which responsibility is given to each position; (3) the main importance of the organisation's mission and values over its employees and directors; and (4) the knowledge and experience of each collaborator as a reason for occupying the related position.

\subsection{International Regime}

As Hasenclever et al (1996) defined as a "consensus definition”, Krasner (1983) affirmed that "regimes can be defined as sets of implicit or explicit principles, norms, rules, and decision-making procedures around which actors' expectations converge in a given area of international relations" whereas (1) norms are "standards of behaviour defined in terms of rights and obligations"; (2) rules are "specific prescriptions or proscriptions for actions; and (3) decision-making procedures are "prevailing practices for making and implementing collective choice".

In order to have a better understanding on the set of norms, rules and decisionmaking procedures it is essential that international players such as INGOs have a deep knowledge on international regimes. Hasenclever et al (1996) and Krasner (1983) describe a great variety of them, such as the interest-based contractualists, cooperationbased liberals and power-based realists. Howsoever, INGOs should perceive that the real world may be composed not only by pure theoretical models - or ideal types - but also by the mix of diverse (un)studied regimes. Understanding them is a step ahead in predicting threats and potentials.

The key point about international regimes is that, before joining a specific country's political arena, INGOs must be able to perceive its historical background and evaluate its government and people, as they tend to react according to pre-existing "norms, rules and decision-making procedures" (Krasner, 1983). For that, "regimes must be understood as something more than temporary arrangements that change with every shift in power or interest" as its purpose is to "facilitate [long term] agreements" (Krasner, 1983). Promoting changes on it is a really difficult task that demands weakening it first by directing efforts to let its "principles, norms, rules, and decisionConjuntura Global, vol. 5 n. 2, mai./ago., 2016, p. 293 - 303. 
making procedures (...) [to] become less coherent" or to put on evidence its inconsistency (Krasner, 1983). Understanding and being able to influence international regimes, INGOs have their voice heard at Global Governance forums - which is the main objective of this paper.

\subsection{Global Governance}

The concept of global governance was built in a historical process that culminated in the end of the Cold War, in 1990, when the former German chancellor Willy Brandt

\footnotetext{
"brought together the members of four eminent global commissions - the Brandt Commission on development, the Palme Commission on disarmament, the Brundtland Commission on sustainable development and the South Commission on co-operation among developing countries [- to a meeting that] led to the creation of a Commission on Global Governance in September 1992, which reported in August 1994 with wide-ranging proposals on global security, economic interdependence, reform of the UN and strengthening international law" (Willetts, 2011).
}

The aim of this commission and its proposals was to build a consensus on political and economic issues that should be followed as a global regime strong enough to aggregate not only states but also intragovernmental organisations, INGOs, transnational companies and individuals.

James Rosenau, former president of the International Studies Association, also stated that those "systems of rule can be maintained and their controls successfully and consistently exerted even in the absence of legal or political authority" (apud Willetts, 2011). Even if it could be considered a generic and subjective approach, the general idea was to make global governance not a hierarchical institution but, as it was mentioned, a consensus capable of conducting international relations even when facing regime divergences. This paper will assume this international consensus as the general - even if simplistic - concept of global governance.

Following Willetts (2011), five characteristics must be added to it: 
1) "Analysis of global governance is focused on decision-making in international organisations", assuming the role of inter-governmental and INGO in the international consensus; 2) "There is not a single system of global governance", respecting the existence of divergences between international and national political actors; 3) "Global governance occurs in all policy domains, whereas writing on interdependence, on regimes and on globalisation has been predominantly from a global political economy perspective"; 4) "Global governance is not reducible to rule-making in regimes", including pre and postregime scenarios, as it may be the cause and also cover consequences of policymaking; and 5) "Global governance implies acceptance of the argument that power is not just the ability to exercise coercion", following the constructivist theory and, as an example, the ability of non-governmental actors to promote change (WILLETTS, 2011).

The main point about global governance is that, accepting it, State-actors are willing to defer authority to INGOs. As Barnett and Finnemore (2005) stated, "there is always a range of opinions about any contentious political problem, but not all views receive equal weight or equal hearing". Having its authority granted by the global community, INGOs' voices are "heard, recognized and believed" (Barnett and Finnemore, 2005).

\section{Conclusions}

Speaking credible, as Barnett and Finnemore (2005) described, "is central to the way authority produces effects". It provokes individuals and institutions to be "likely to alter their behaviour in the ways that are consistent with the directions laid out", involving "more than the ability to get people to do what they otherwise would not" but consisting "of telling people what is the right thing to do". The referred persuasive credibility exists only when accomplished by an authoritative legitimacy that is given not only by a positive scenario but also by the ability of following numerous procedures that provide enough strength to promote change.

This paper aimed at introducing a conceptual discussion on the key elements present in international non-governmental organizations which have authoritative legitimacy to influence global governance. It started presenting suggestions to the management of these organisations, by showing the importance of having strong and 
desirable values that are not going to be weakened by state influence, business interests or leaders' selfishness. Following this ideal internal model, it was shown that the organisation must also be prepared to face externalities that include a large variety of international regimes - with some that may not be explained by theoretical models and a scenario of global governance constituted by authoritative States suffering pressure from non-governmental actors as other INGOs, transnational organisations, business companies and individual citizens.

By the reviewed literature and the analysis over the most influential international organisations, it is possible to affirm that having a great knowledge over the global scenario, great lobbying skills, desirable values and goals, and following professional management methods, individual citizens are able to mobilize themselves into INGOs with enough credibility and authority to influence global governance. Further efforts in this research area should be directed to evaluate how specific INGOs are working, as a way of checking if they are being able to follow the referred procedures to achieve a maximum efficiency level.

\section{References}

Amnesty International. 2010. Amnesty International website retrieved on December 16, 2010 from http://www.amnesty.org/en/who-we-are.

BARNETT, Michael; FINEMORE, Martha. 2005. The power of liberal international organizations. In BARNETT, Michael; DUVALL, Raymond (Eds.), Power in Global Governance, Cambridge; New York: Cambridge University Press, pp.161-184.

Cato Institute. 2010. Cato Institute website retrieved on December 16, 2010 from http://www.cato.org/about.php.

Chatham House. 2010. Chatham House website retrieved on December 16, 2010 from http://www.chathamhouse.org.uk/about/.

CORNFORTH, Chris. 2003. The governance of public and nonprofit organizations: What do boards do?, London: Routledge.

EYF. 2010. European Youth Forum website, retrieved on December 16, 2010 from http://www.eyf.coe.int/fej.

DOH, Jonathan; TEEGEN, Hildy. 2003. Globalization and NGOs: transforming business, government, and society, Connecticut: Praeger Publishers. 
HASENCLEVER, Andreas; MAYER, Peter; RITTBERGER, Volker. 1996. Interest, Power, Knowledge: The Study of International Regimes. Mershon International Studies Review, 40, pp. 177-228.

KRASNER, Stephen. 1983. International Regimes, Ithaca: Cornell University Press.

UPHOFF, Norman. 2002. Why NGOs are not a Third Sector: a Sectorial Analysis with some Thoughts on Accountability, Sustainability and Evaluation. In EDWARDS, Michael; HULME, David (Eds.), Non-Governmental Organisations: performance and accountability beyond the the Magic Bullet, London: Earthscan Publications Limited. pp. 17-31.

WikiLeaks. 2010. WikiLeaks website retrieved on December 16, 2010 from http://213.251.145.96/About.html.

WILLETTS, Peter. 2002. What is a Non-Governmental Organization?. In UNESCO (Eds.), Encyclopedia of Life Support Systems: Encyclopedia of Institutional and Infrastructural Resources, Oxford: Eolss Publishers.

WILLETTS, Peter. 2011. Non-Governmental Organizations in World Politics: The construction of global governance (Global Institutions), London: Routledge. 